\title{
HUBUNGAN PENINGKATAN BERAT BADAN DAN KETIDAKTERATURAN SIKLUS HAID DENGAN PENGGUNA KB SUNTIK PADA AKSEPTOR KB DI PUSKESMAS PEMBINA PALEMBANG TAHUN 2018
}

\author{
Bina Aquari \\ Akademi Kebidanan Budi Mulia Palembang
}

\author{
A B S T R A K
}

Informasi Artikel :

Diterima : April 2018

Disetujui : Mei 2018

Dipublikasikan : Juni 2018

*Korespondensi Penulis : Binaplb2201@gmail.com
Kontrasepsi Hormonal sebagai salah satu alat Kontrasepsi meningkat dan tajam. Menurut World Health Organization (WHO) 2014, Pengguna alat kontrasepsi suntik yaitu $35,3 \%$, pil yaitu $30,5 \%$, IUD yaitu $15,2 \%$, Implant $7,3 \%$, dan $11,7 \%$ Kontrasepsi lainnya. Tujuan penelitian ini untuk mengetahui apakah ada hubungan peningkatan berat badan dan ketidakteraturan siklus haid dengan KB suntik pada akseptor KB di Puskesmas Pembina Palembang Tahun 2018.Rumusan masalah penelitian ini adalah hubungan antara umur dan pengetahuan akseptor tentang $\mathrm{KB}$ Suntik di Puskesmas Pembina Palembang Tahun 2018.Penelitian ini menggunakan survey analitik dengan pendekatan cross sectional yang dilakukan dengan kuesioner.Uji Statistic yang dipakai adalah Uji Chi-Square. Populasi dalam penelitian ini berjumlah 62 orang dan seluruh Populasi dijadikan sampel. Dari hasil analisa univariat responden yang memakai KB Suntik lebih besar yaitu sebanyak 36 orang $(58,1 \%)$, dan 26 orang $(41,9 \%)$ yang tidak memakai KB Suntik. Responden yang berat badannya meningkat memakai kontrasepsi sebanyak 33 orang $(53,2 \%)$, sedangkan responden yang berat badannya tidak meningkat sebanyak 29 orang $(46,8 \%)$ dibandingkan dengan responden yang siklus haidnya tidak teratur adalah sebanyak 32 orang $(51,6 \%)$. Hasil analisa statistik dengan menggunakan Uji Chi-Square dengan df $=1$ ada hubungan yang bermakna peningkatan berat badan dengan KB Suntik pada akseptor KB diperoleh $p$ value (0.006) lebih kecil dari $(0,05)$ dan ada hubungan yang bermakna ketidakteraturan siklus haid dengan $\mathrm{KB}$ suntik pada akseptor $\mathrm{KB}$ diperoleh $p$ value $(0,011)$ lebih kecil dari $(0,05)$. Saran agar petugas kesehatan meningkatkan kinerja dan sistem informasi mengenai masalah yang berhubungan dengan pemakaian KB Suntik.

Kata Kunci : Pemakaian KB suntik

\section{ABSTRACT}

The hormonal contraception as becoming on of the contraceptions tools which is increasing sharply. Based on world Health Organitation (WHO) the user of injected contraception is $35,3 \%$, pill 30,5\%, IUD 15\%, implant 7,3\%, and $11,7 \%$ for another contraception. The purpose of this research is for knowing wheter there is the increasing of weight and the irregular of monthly period with injected contraception for the acceptor at Puskesmas Pembina Palembang in 2014. The main case of this research is the relationship between the increasing of the weight and the irregular monthly period at Puskesmas Pembina Palembang in 2014. This research using analytic survey with cross sectional closing yhat was done by using questioner, the statistic test which take is Chi-Square test. The population in this reseacrh are 62 peoples, and all off them as becoming the sample from the result of respondent univariat analyze whom using the injected contraception in bigger that is exactly 36 people $(58,1 \%)$ and 26 people $(41,9 \%)$ whom do not using it. The respondent with their weight is increasing because of using contraception is 33 people $(53,2 \%)$, while the respondent whom the weight do not increasing is 29 people $(46,8 \%)$, when we compare with the respondent whom the monthly period is irregular are 32 people $(51,6 \%)$. The result for statistic analyze by using the Chi-Square test with the $d f=1$ says that there is a significant relationship between the weight increasing with the injected contraception for the acceptor we get $p$ value $(0,006)$ is smaller than $(0,05)$ and there is significant relationship between the injected contraception for the acceptor we get $p$ value $(0,011)$ with is smaller than $(0,05)$. The sugestion of the health workes to increasing the performance the information sistem about the problem that is connected with the inject contraception using

Key Point : Inject Contraseption Using 


\section{PENDAHULUAN}

Indonesia merupakan sebuah negara berkembang dengan jumlah peningkatan penduduk yang tinggi. Data Sasaran menyebutkan bahwa jumlah penduduk Indonesia adalah 237.556.363 orang, terdiri atas 119.507 .600 pria dan 118.048.783 wanita, penduduk ini tentu saja berimplikasi secara siknifikan terhadap perkembangan ekonomi dan kesejahteraan negara (Irianto, 2014).

Kontrasepsi suntikan adalah cara untuk mencegah terjadinya kehamilan dengan melalui suntikan hormonal. Kontrasepsi hormonal jenis KB suntikan ini di Indonesia semakin banyak dipakai karana kerjanya yang efektif, pemakaiannya yag praktis, harganya relatif murah dan aman (Martini, 2011).

Faktor-faktor yang mempengaruhi dari penggunaan $\mathrm{KB}$ suntik yaitu gangguan haid, depresi, keputihan, jerawat, rambur rontok, perubahan berat badan, jerawat, perubahan libido (Irianto, 2014).

Pencapaian Akseptor KB di Puskesmas Pembina Palembang Tahun 2018 berjumlah 2712 Akseptor, IUD 242 orang, Pil 812 orang, Suntikan 1180 orang, Implan 278 orang, MOW 63 orang, Kondom 137 Orang (Puskesmas Pembina, 2018).

Berdasarkan latar belakang di atas Kontrasepsi hormonl jenis KB suntikan di Indonesia semakin banyak dipakai karena kerjanya efektif, pemakaiaanya praktis, harganya relatif murah dan aman.

Berdasarkan identifikasi masalah di atas, karna keterbatasan tenaga, pikiran, biaya dan waktu maka, peneliti hanya meneliti 2 variabel yaitu peningkatan berat badan dan ketidak teraturan siklus haid sebagai variabel independen dengan pengguna KB suntik sebagai variabel dependen pada akseptor KB di Puskesmas Pembina Palembang Tahun 2018.

Diketahui hubungan peningkatan berat badan dan ketidakteraturan siklus haid secara simultan dengan pengguna KB suntik pada akseptor KB di Puskesmas Pembina Palembang tahun 2018.

Penggunaan kontrasepsi suntik memiliki pengaruh terhadap Peningkatan berat badan penggunanya, hal itu dapat terjadi karena adanya hormon progesteron yang mempermudah perubahan karbohidrat dan gula menjadi lemak sehingga lemak dibawah kulit bertambah. Selain itu hormon progesteron juga menyebabkan nafsu makan bertambah. Pemakaian kontasepsi ini juga berpengaruh terhadap siklus haid, biasanya siklus haid pengguna menjadi tidak teratur dikarenakan adanya ketidak seimbangan hormon sehingga endometrium mengalami perubahan histologi.

\section{METODE PENELITIAN}

Desain penelitian adalah macam atau jenis penelitian tertentu yang terpilih untuk dilaksanakan dalam rangka mencapai tujuan penelitian yang telah ditentukan (Prihartono, 2014)

Penelitian ini bersifat kuantatif mengunakan metode survey analitik dengan pendekatan cross sectional. Dimana semua variabel, baik variabel devenden KB suntik maupun indevenden peningkatan berat badan dan ketidak teraturan siklus haid di kumpulkan sekaligus dalam waktu yang bersamaan (Notoatmojo,2010).

Waktu penelitian dilaksanakan pada Bulan Maret - April 2018 di Puskesmas Pembina Palembang.

Populasi dalam penelitian ini adalah jumlah keseluruhan dari objek yang diteliti. Populasi penelitian ini adalah semua ibu akseptor KB yang datang ke Puskesmas Pembina Palembang pada Bulan Maret - April 2018 yang berjumlah 62 responden.

Sampel diambil dari jumlah populasi hal ini sesuai dengan teori Arikunto yang mengatakan jika populasi kurang dari 100 orang maka seluruh populasi di jadikan sampel. (Arikunto, 2013) Pengambilan sampel menggunakan metode non random dengan teknik Accidental Sampling yaitu seluruh ibu-ibu akseptor KB suntik yang datang ke Puskesmas Pembina Palembang pada Bulan MaretApril 2018, karena selama penenlitian akseptor KB yang datang ke Puskesmas Pembina Palembang hanya 62 responden maka semuanya dijadikan sampel.

Pengumpulan data dalam penelitian ini menggunakan data primer yaitu data yang didapat dari hasil wawancara langsung dengan responden dengan menggunakan kuesioner.

Analisis data yang digunakan untuk mengetahui hubungan antara variabel dependen (Kontrasepsi Suntikan) dengan variabel independen (Peningkatan Berat Badan dan ketidakteraturan Siklus haid), sehingga dapat diketahui apakah ada hubungan antara Kontrasepsi Suntikan dengan Peningkatan Berat Badan dan Ketidakteraturan Siklus haid di Puskesmas Pembina palembang pada bulan Maret-April Tahun 2018. Penelitian ini menggunakan uji statistik "chi square" dengan sistem komputerisasi SPSS.. 


\section{HASIL PENELITIAN DAN PEMBAHASAN}

Pada penelitian ini akseptor KB aktif berjumlah 62 orang dimana pengguna alat kontrasepsi dibagi menjadi dua kategori yaitu pemakaian alat kontrasepsi suntik dan pemakai alat kontrasepsi selain suntik, untuk lebih jelasnya dapat dilihat pada tabel dibawah ini.

Tabel 1. Distribusi Frekuensi Berdasarkan Pemakaian Alat Kontrasepsi Suntik Pada Akseptor KB di Puskesmas Pembina Palembang Tahun 2018

\begin{tabular}{ccc}
\hline $\begin{array}{c}\text { Pemakaian Alat } \\
\text { Kontrasepsi Suntik }\end{array}$ & F & \% \\
\hline Ya & 36 & 58,1 \\
Tidak & 26 & 41,9 \\
\hline
\end{tabular}

Dari tabel 1diatas, dapat diketahui bahwa dari 62 responden, ibu yang memakai alat kontrasepsi suntik yaitu sebanyak 36 responden $(58,1 \%)$ dan yang memakai alat kontrasepsi selain suntik yaitu sebanyak 26 responden $(41,9 \%)$.

Pada penelitian ini peningkatan berat badan akseptor dibagi menjadi dua katagori yaitu apabila berat badan ibu meningkat dan apabila berat badan ibu tidak meningkat. Untuk lebih jelasnya dapat dilihat pada tabel berikut.

Tabel 2. Distribusi Frekuensi Berdasarkan Peningkatan Berat Badan pada Akseptor KB di Puskesmas Pembina Palembang Tahun 2018

\begin{tabular}{ccc}
\hline Peningkatan Berat Badan & F & \% \\
\hline Meningkat & 33 & 53,2 \\
Tidak Meningkat & 29 & 46,8 \\
\hline
\end{tabular}

Berdasarkan Tabel 2 dapat dilihat dari 62 responden, akseptor yang mengalami peningkatan berat badan 33 orang $(53,2 \%)$ dan akseptor yang tidak mengalami peningkatan berat badan sebesar 29 orang $(46,8 \%)$.

Pada penlitian ini ketidakteraturan Siklus Haid menjadi dua katagori yaitu apabila siklus haid ibu tidak teratur dan apabila siklus haid ibu tetap teratur. Untuk lebih jelas dapat dilihat pada tabel di bawah ini.

Tabel 3. Distribusi Frekuensi Berdasarkan Ketidakteraturan Siklus Haid Pada Akseptor KB di Puskesmas Pembina Palembang Tahun 2018

\begin{tabular}{lcc}
\hline $\begin{array}{l}\text { Ketidak Teratur Siklus } \\
\text { Haid }\end{array}$ & F & \% \\
\hline Tidak Teratur & 32 & 51,6 \\
Teratur & 30 & 48,4 \\
\hline
\end{tabular}

Berdasarkan Tabel 3 diatas dari 62 responden,ibu yang siklus haid menjadi tidak teratur sebesar 32 orang $(51,6 \%)$ sedangkan yang siklus haid tetap teratur sebesar 30 orang $(48,4 \%)$.

Pada penelitian ini peningkatan berat badan Ibu dengan penggunaan alat kontrasepsi suntik di bagi menjadi dua kategori yaitu berat badan meningkat dan berat badan tidak meningkat. Sedangkan pada pemakaian alat Akseptor dibagi menjadi dua katagori yaitu

Tabel 4. Hubungan Peningkatan Berat Badan dengan Pengguna KB Suntik pada Akseptor KB di Puskesmas Pembina Palembang Tahun 2018

\begin{tabular}{|c|c|c|c|c|c|c|}
\hline \multirow{3}{*}{$\begin{array}{l}\text { Berat } \\
\text { Badan }\end{array}$} & \multicolumn{4}{|c|}{ Kontrasepsi Suntik } & \multirow{2}{*}{\multicolumn{2}{|c|}{ Jumlah }} \\
\hline & \multicolumn{2}{|r|}{$\mathbf{Y a}$} & \multicolumn{2}{|c|}{ Tidak } & & \\
\hline & $\mathbf{F}$ & $\%$ & f & $\%$ & $\mathbf{F}$ & $\%$ \\
\hline Meningkat & 25 & $75,8 \%$ & 8 & $24,2 \%$ & 33 & $100 \%$ \\
\hline $\begin{array}{l}\text { Tidak } \\
\text { Meningkat }\end{array}$ & 11 & $37,9 \%$ & 18 & $62,1 \%$ & 29 & $100 \%$ \\
\hline Jumlah & 36 & & 26 & & 62 & $100 \%$ \\
\hline
\end{tabular}

Berdasarkan Tabel 4 dilihat bahwa ada Dari hasil analisa diatas diketahui dari 62 responden ibu yang mengalami peningkatan berat bada ada 33 orang, yang menggunakan kontrasepsi suntikan sebanyak 25 orang $(75,8 \%)$ yang menggunakan kontrasepsi selain suntik sebanyak 8 orang $(24,2 \%)$. Ibu yang tidak mengalami peningkatan berat badan ada 29 orang, yang menggunakan kontrasepsi suntik sebanyak 11 orang $(37,9 \%)$, dan yang menggunakan kontrasepsi selain suntik sebanyak 18 orang $(62,1 \%)$. Dari hasil uji statistik Chi-Square, didapat nilai $P$ Value sebesar $0,006 \leq$ $\alpha 0,05$ artinya ada hubungan yang bermakna antara peningkatan berat badan dengan penggunaan KB suntik di puskesmas Pembina Palembang Tahun 2018.

Hasil penelitian ini sesuai dengan penelitian Mawar Yusnita Saleh tahun 2012 terbukti bahwa KB suntik mampu menghasilkan perbedaan terhadap peningkatan berat badan sesudah menggunakan KB suntik, hal ini terbukti dari hasil anlisis statistik menggunakan uji $T$ test dimana nilai $P$ Value $=0,00$ yang berarti ada perbedaan terhadap berat badan sebelum dan sesudah menggunakan KB suntik.

Hasil penelitian ini sesuai dengan penelitian yang dilakukan University of Texas Medical Branch (UTMB) tahun 2008, hal ini terbukti penggunaan kontrasepsi suntik memiliki resiko 2 kali lipat dibandingkan pengguna kontraspsi lainnya untuk mengalami obesitas.

Hasil penelitian ini sesuai dengan penelitian Dwi Haryani tahun 2010, pengaruh frekuensi 
kontrasepsi suntik terhadap kenaikan berat badan pada akseptor kontrasepsi suntik adalah $16,1 \%$ dengan persamaaan garis regresi $\mathrm{Y}=4,830+0,11 \mathrm{X}$ sehingga semakin banyak akseptor melakukan suntik maka berat badan juga cenderung akan meningkat.

Menurut hasil penelitian saya yang meneliti hubungan peningkatan berat badan dengan $\mathrm{KB}$ suntik pada akseptor KB di Puskesmas Pembina Palembang yaitu ada hubungan peningkatan berat badan dengan KB suntik pada akseptor KB karena jumlah berat badan ibu yang meningkat lebih tinggi dibandingkan dengan jumlah berat badan ibu yang tidak meningkat.

Tabel 5. Hubungan Ketidakteraturan Siklus Haid dengan Pengguna KB suntik pada Akseptor KB di Puskesmas Pembina Palembang Tahun 2018.

\begin{tabular}{lllllll}
\hline Ketidak & \multicolumn{3}{c}{ Kontrasepsi Suntik } & \multirow{2}{*}{ Jumlah } \\
\cline { 2 - 6 } Teraturan & \multicolumn{2}{c}{ Ya } & \multicolumn{2}{c}{ Tidak } & & \\
\cline { 2 - 6 } Siklus Haid & f & \% & f & \% & F & \% \\
\hline Tidak & $\mathbf{2 4}$ & $\mathbf{7 5 , 0 \%}$ & $\mathbf{8}$ & $\mathbf{2 5 , 0 \%}$ & $\mathbf{3 2}$ & $\mathbf{1 0 0 \%}$ \\
Teratur & & & & & & \\
\hline Teratur & $\mathbf{1 2}$ & $\mathbf{4 0 , 0 \%}$ & $\mathbf{1 8}$ & $\mathbf{6 0 , 0 \%}$ & $\mathbf{3 0}$ & $\mathbf{1 0 0 \%}$ \\
\hline Jumlah & $\mathbf{3 6}$ & & $\mathbf{2 6}$ & & $\mathbf{6 2}$ & $\mathbf{1 0 0 \%}$ \\
\hline
\end{tabular}

Berdasarkan Tabel 5 dilihat bahwa Hasil analisa di atas dari 62 responden, ibu yang siklus haidnya menjadi tidak teratur sebanyak 32 orang, yang menggunakan kontrasepsi suntik sebanyak 24 orang $(75,0 \%)$, yang menggunakan kontrasepsi selain suntik sebanyak 8 orang $(25,0 \%)$, dan ibu yang siklus haidnya tetap teratur ada 30 orang, yang memakai kontrasepsi suntik sebanyak 12 orang $(40,0 \%)$, dan yang memakai kontrasepsi selain suntik sebanyak 18 orang $(60,0 \%)$. dari hasil uji statistik Chi-Square, didapat nilai $P$ Value sebesar $0,011 \leq \alpha 0,05$ artinya ada hubungan yang bermakna ketidakteraturan siklus haid dengan penggunaan KB suntik di Puskesmas Pembina Palembang Tahun 2018.

Dari hasil analisis bivariat dengan uji ChiSquare diperoleh $P$ Value sebesar $0,011 \leq \alpha 0,05$ berarti ada hubungan yang bermakna antara ketidakteraturan siklus haid dengan penggunaan alat kontrasepsi suntik. Dengan demikian hipotesis menyatakan ada hubungan ketidakteraturan siklus haid dengan KB suntik pada akseptor KB di Puskesmas Pembina Palembang terbukti secara statistik.

Hasil penelitian ini sesuai dengan penetitian Agustina Catur Setyaningrum tahun 2008 menunjukkan bahwa pengguna KB suntik dari 29 akseptor yang mempunyai siklus haid normal hanya 4 orang sedangkan sisanya tidak mengalami menstruasi dari hasil uji statistik menunjukkan $P$ Value 0,012 dan $\mathrm{r}=0,341$.

Hasil penelitian ini sesuai dengan penelitian Riyanti Januani tahun 2012 di peroleh hasil pemakaian kontrasepsi suntik baik 1 bulan maupun 3 bulan akan mengalami gangguan siklus haid, pengguna kontrsepsi suntik 3 bulan kemungkinan untuk mengalami gangguan haid 18,2 kali lebih besar dibandingkan responden yang menngunakan kontrasepsi suntik 1 bulan.

Hasil penelitian saya yang meneliti hubungan ketidakteraturan siklus haid dengan KB suntik pada akseptor KB di Puskesmas Pembina Palembang ada hubungan ketidakteraturan siklus haid dengan pengguna KB suntik pada akseptor KB karen jumlah akseptor yang mengalami ketidakteraturan siklus haid lebih banyak dibandingkan dengan jumlah akseptor yang siklus haidnya tetap teratur.

\section{KESIMPULAN}

Hampir separuh responden menggunakan $\mathrm{kb}$ suntik. Sebagian besar responden yang menggunakan $\mathrm{KB}$ suntik mengalami peningkatan berat badan. Hanya sedikit yg tidak mengalami kenaikan berat badan. Terdapat hubungan yang bermakna antara peningkatan berat badan dengan pengguna KB suntik pada akseptor KB di Puskesmas Pembina Palembang. Terdapat hubungan yang bermakna antara ketidakteraturan siklus haid secara dengan pengguna KB suntik pada akseptor KB di Puskesmas Pembina Palembang.

\section{SARAN}

Diharapkan Pimpinan Puskesmas Pembina Palembang terus meningkatkan dan mengembangkan mutu pelayanan kesehatan khususnya pelayanan dalam program keluarga berencana di wilayah kerjanya.

Disarankan kepada penelitian selanjutnya untuk meneliti variabel gangguan haid, depresi, keputihan, jerawat, rambut rontok, perubahan berat badan, jerawat, perubahan libido.

\section{DAFTAR PUSTAKA}

Affandi, Biran. 2012. Buku Panduan Praktis Pelayanan Kontrasepsi. Jakarta : PT Bina Pustaka Sarwono Prawirohardjo.

Anggraini, Yetti. 2011. Pelayanan Keluarga Berencana. Yogyakarta : Rohima Press.

Arikunto, Suharsimi. 2013. Prosedur Penelitian. Jakarta : Rineka Cipta. 
Irianto, Koes. 2014. Pelayanan Keluarga Berencana Dua Anak Cukup. Bandung : Alfabeta.

Noto Atmodjo, soekidjo. 2010. Metodelogi Penelitian Kesehatan. Jakarta : Reneca Citra.

Prihartono, Joedo. 2014. Metode Penelitian Kedokteran dan Kesehatan Masyarakat. Jakarta : Binarupa Aksara.

Setya Arum, Dyah Noviawati. 2009. Panduan Lengkap Pelayanan KB Terkini. Yogyakarta : Nuha Medika.

Siti Mulyani, Nina. 2013. Keluarga Berencana dan Alat Kontrasepsi. Yogyakarta : Nuha Medika.

Sulistyawati, Ari. 2011. Pelayanan Keluarga Berencana. Jakarta : Salemba Medika.

Anugrah Nilasari, Tika. 2013. Konsep Dasar KB. http://www.Konsep-dasarKB.com/artikel/detik/detail

BKKBN. 2013. Ringkasan Laporan Hasil Pelayanan Kontrasepsi Maret Tahun 2013. http://bkkbn.co.id/laporan.pelayanan.kont rasepsi.

Dwi Haryani, Dewi.2010. Pengaruh Frekuensi Kontrasepsi Suntik DMPA Terhadap Kenaikan Berat Badan Pada Akseptor Kontrasepsi Suntik DMPA. Jurnal Ilmiah Kebidanan : Poltekes Semarang. http://www.Jurnal.kesehatan.com

Dinkes Kota Palembang. 2012. Profil Kesehatan Kota Palembang Tahun 2012. http://dinkes.palembang.go.id/tampung/d okumen/dokumen-87-120.pdf .2012. BKKBN Sumsel Targetkan $405.920 \quad$ Peserta KB. http://www.Sripoku.com.Palembang

Januani Anggia, Riyanti. 2012. Hubungan Jenis dan Lama Pemakaian Komtrasepsi Hormonal dengan Gangguan Menstruasi di BPS Wolita M.J Sawong Kota Surabaya : Universitas Airlangga. http://www.Jurnal.kesehatan.com

Kompas. 2008. KB Suntik Paling Dingemari Ibu$\mathrm{Ibu}$.

http.//nasional.kompas.com/read/2008/05 130/20114988.KB.suntik.paling.digemari. ibu.ibu.

Ny Sukmasari, Radian. 2013. Pil dan Suntik Kontrasepsi Terfavorit di Indonesia. http://www.kontasepsi.tervaforit.com/deti kHealth/.

Suparyanto. 2010. Pengaruh KB Suntik Terhadap Perubahan Berat Badan.
Yusnita Saleh, Mawar. 2012. Pengaruh KB Hormonal dan Non Hormonal Terhadap Berat Badan Akseptor di Puskesmas Kebayakan Kec.Kebayakan Kabupaten Acah Tengah Tahun 2012. Jurnal Kesehatan Masyarakat.Stikes Budiyah. http://www.Jurnal.kesehatan.com : 
